УДК 61:378.1:37.022

\title{
ПОПЕРЕДНІ ПІДСУМКИ ЗАПРОВАДЖЕННЯ КРЕДИТНО- МОДУЛЬНОЇ СИСТЕМИ ОРГАНІЗАЦІЇ НАВЧАЛЬНОГО ПРОЦЕСУ У ВИЩИХ МЕДИЧНИХ НАВЧАЛЬНИХ ЗАКЛАДАХ ТА ШЛЯХИ ПОДАЛЬШОГО УДОСКОНАЛЕННЯ ЙОГО ОРГАНІЗАЦІЇ
}

\author{
В. В. Вороненко ${ }^{1}$, О. П. Волосовець ${ }^{1}$, Ю. С. П'ятницький ${ }^{1}$, І. С. Вітенко
} І. В. Мельник ${ }^{2}$, І. С. Булах ${ }^{3}$, М. Р. Мруга ${ }^{3}$

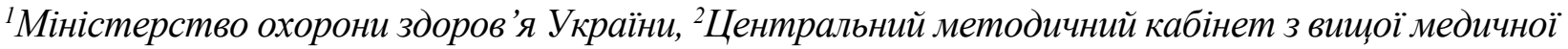
освіти МОЗ Украӥни, ${ }^{3}$ Центр тестування професійної компетентності фахівців з вищою освітою напрямів підготовки "Медицина" $i$ “Фармація"

\section{FORMER RESULTS OF IMPLEMENTATION OF CREDIT-MODULAR SYSTEM OF EDUCATIONAL PROCESS ORGANIZATION IN HIGHER MEDICAL EDUCATIONAL INSTITUTIONS AND THE WAYS OF FURTHER IMPROVEMENT OF ITS ORGANIZATION}

\author{
V. V. Voronenko ${ }^{1}$, O. P. Volosovets ${ }^{1}$, Yu. S. Pyatnytskyi ${ }^{1}$, I. S. Vitenko², I. V. Melnyk ${ }^{2}$, \\ I. Ye. Bulakh ${ }^{3}$, M. R. Mruha ${ }^{3}$ \\ ${ }^{1}$ Ministry of Public Health of Ukraine, ${ }^{2}$ Central Methodical Cabinet on Higher Medical Education of \\ MPH of Ukraine, ${ }^{3}$ Center of testing of professional competence of specialists with higher education of \\ training directions "Medicine" and "Pharmacy"
}

\footnotetext{
У статті підсумовано впровадження кредитно-модульної системи навчання у медичних навчальних закладах. Вказано на проблеми і перспективи цього процесу.
}

The article summarized the implementation of credit-modular education system in medical educational establishments. The problems and prospects of this process are considered.

На зустрічі міністрів, що відповідають за вищу освіту у країнах-учасницях Болонського процесу, яка відбулася 11-12 березня 2010 року у Будапешті та Відні, схвалено Будапештсько-Віденську декларацію та офіційно проголошено створення Свропейського простору вищої освіти.

Міністерство охорони здоров'я України запроваджує кредитно-модульну систему організації навчального процесу у вищих медичних (фармацевтичному) навчальних закладах України III-IV рівнів акредитації MO3 України з 2004 року (наказ MO3 України від 22.03.2004 № 148 “Про заходи щодо реалізації положень Болонської декларації в системі вищої медичної та фармацевтичної освіти”) на виконання Указу Президента України від 17.02.2004 № 199/2004 "Про заходи щодо вдосконалення системи вищої освіти України" та наказу Міністерства освіти і науки Ук- раїни від 23.01.2004 № 49 “"Про затвердження Програми дій щодо реалізації положень Болонської декларації в системі вищої освіти і науки України на 2004 2005 роки".

У комюніке конференції європейських міністрів вищої освіти 2009 року (28-29 квітня 2009 року, Льовен (Фландрія) та Лювен-ля-Ньов (Валлонія), головними темами якої було взаємне визнання дипломів та періодів навчання, гармонізація механізмів забезпечення якості вищої освіти, моніторинг реалізації Болонського процесу, зазначено: "У наступному десятилітті європейська вища освіта має здійснити істотний внесок для побудови високо креативної та інноваційної Європи знань. Стикаючись із викликом старіння населення, Свропа може досягти успіху у своїх зусиллях тільки тоді, коли надасть найбільшого розвитку талантам та здібностям усіх своїх гро-

() В. В. Вороненко, О. П. Волосовець, Ю. С. П’ятницький та ін. 
мадян та повною мірою вдасться до розвитку ціложиттєвого навчання і розширення залученості (parbicipaton) до вищої освіти [1]. У п.12 вказаного комюніке пріоритетом вищої освіти у наступному десятилітті визначено розробку національних структур кваліфікацій, як важливого кроку до розвитку навчання упродовж всього життя. Наша мета полягає у тому, аби не пізніше 2012 року національні структури кваліфікацій були завершені та підготовлені до самосертифікації відносно загальної структури кваліфікацій Європейського простору вищої освіти - витяг 3 комюніке.

Зауважимо, що затвердження Плану заходів щодо впровадження Національної рамки кваліфікацій в Україні передбачено Національним планом дій щодо впровадження Програми економічних реформ на 2010-2014 роки “Заможне суспільство, конкурентоспроможна економіка, ефективна держава” у 20122014 роках. Отже, подальша робота Міністерства та вищих медичних навчальних закладів буде також пов' язана з розробкою та впровадженням Національної рамки кваліфікацій.

На виконання наказу МО3 України від 11.11.2011 № 782 “Про впровадження Рішення наради ректорів вищих медичних (фармацевтичного) навчальних закладів IV рівня акредитації та закладів післядипломної освіти MOЗ України “Підсумки проведення вступної кампанії до вищих навчальних закладів МОЗ України у 2011 році. Актуальні питання поліпшення якості та організації підготовки медичних та фармацевтичних спеціалістів" від 11.10.2011" Міністерством охорони здоров'я України, Центральним методичним кабінетом з вищої медичної освіти МОЗ України було проаналізовано результати державної атестації випускників вищих медичних навчальних закладів IV рівня акредитації у 2000-2011 роках - до та після впровадження системи кредитно-модульної організації навчального процесу.

Зазначаємо, що 2011 року в Україні відбувся перший випуск випускників вищих медичних навчальних закладів, які пройшли повний курс навчання за кредитно-модульною системою організації навчаль- ного процесу відповідно до наказу МОЗ України від 31.01.2005 № 52 “Про затвердження та введення нового навчального плану підготовки фахівців освітньо-кваліфікаційного рівня “спеціаліст” кваліфікації “лікар” у вищих медичних навчальних закладах України III-IV рівнів акредитації України за спеціальностями “Лікувальна справа", "Педіатрія", “Медикопрофілактична справа” [2].

Цей навчальний план був підготовлений робочою групою з розробки стратегічних і тактичних завдань, що стоять перед MO3 України у контексті Болонського процесу, склад якої затверджено наказом МОЗ України від 14.04.2004 № 198, і якою проаналізовано 42 навчальних плани медичних факультетів 19 країн світу [4].

Державна атестація випускників вищих медичних навчальних закладів проводиться у формі стандартизованого тестового державного іспиту (ліцензійний інтегрований іспит (ЛІІ) Міністерства охорони здоров’я України “Крок”), який вимірює рівень професійної компетентності фахівця, та практично-орієнтованого державного іспиту, яким оцінюється здатність випускника вирішувати типові задачі діяльності лікаря в умовах, наближених до професійної діяльності.

Як свідчать результати державної атестації випускників у 2011 та 2010 роках за даними практично-оріснтованого державного іспиту за спеціальністю "Лікувальна справа" в розрізі вищих навчальних закладів у порівнянні з показниками 2000-2001 років у половині навчальних закладів відмічено зниження середнього бала успішності випускників, спостерігасться тенденція до збільшення кількості студентів, які склали екзамени на “відмінно” та “добре”, зменшення тих, які отримали лише “задовільно” (НМУ ім. О. О. Богомольця, ЛДМУ, ОНМУ, ТДМУ, ХНМУ).

Мас місце зменшення кількості випускників, які отримали дипломи з відзнакою (БДМУ, ЗДМУ, ІФНМУ, ЛНМУ ім. Данила Галицького, ТДМУ), а також зниження середнього бала успішності іноземних студентів у більшості навчальних закладів (виключення ОНМУ, УМСА, ХНМУ).

\begin{tabular}{|c|c|c|c|c|c|c|c|c|c|c|c|c|c|c|}
\hline Рік & \multicolumn{14}{|c|}{ Назва навчального закладу } \\
\hline $\begin{array}{c}\text { Бал/ } \\
\text { Якість } \\
\text { Успіш. }\end{array}$ & 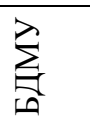 & $\sum_{\infty}^{2}$ & $\sum_{\Xi}^{\Xi}$ & $\sum_{i}^{\lambda}$ & 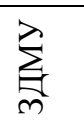 & $\sum_{\underline{\theta}}^{\lambda}$ & $\sum_{3}^{2}$ & $\sum^{Z}$ & $\sum_{\text {至 }}^{\lambda}$ & $\sum_{\underline{I}}^{\gtrsim}$ & $\sum_{0}^{2}$ & $\sum_{i}^{Z}$ & 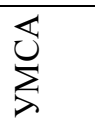 & 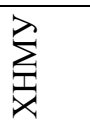 \\
\hline \multirow[t]{2}{*}{2011} & 3,89 & 3,67 & 3,9 & 4,0 & 3,92 & 4,1 & 4,14 & 3,98 & 3,93 & 4,23 & 4,05 & 3,72 & 4,0 & 3,89 \\
\hline & 72,72 & 56,63 & 75,62 & 79,0 & 64,5 & 73,7 & 94,41 & 38,0 & 65,52 & 72,0 & 93,39 & 52,71 & 96,96 & 51,33 \\
\hline \multirow[t]{2}{*}{2010} & 3,97 & 4,11 & 4,09 & 4,2 & 4,01 & 4,15 & 4,26 & 3,98 & 3,92 & 4,05 & 4,08 & 3,73 & 4,0 & 3,98 \\
\hline & 69,96 & 73,81 & 80,57 & 84,8 & 71,2 & 76,9 & 85,2 & 58,7 & 56,42 & 52,6 & 87,42 & 52,51 & 94,28 & 54,94 \\
\hline 2001 & 3,9 & 3,9 & 3,8 & 3,9 & 3,8 & 4,0 & 4,1 & 4,0 & 3,9 & 4,0 & 3,9 & 3,9 & 4,1 & 3,8 \\
\hline 2000 & 4,1 & 3,91 & 3,8 & 3,9 & 3,8 & 3,9 & 4,1 & 4,0 & 3,9 & 4,1 & 3,8 & 3,8 & 4,0 & 3,9 \\
\hline
\end{tabular}


Матеріали Всеукраїнської навчально-наукової конференції, присвяченої 55-річчю Тернопільського державного медичного університету імені І. Я. Горбачевського, “Впровадження нових технологій за кредитно-модульної системи організації навчального процесу у ВМ(Ф)НЗ III-IV рівнів акредитації”

Порівняльний аналіз результатів свідчить, що є тенденція до зростання середнього бала у випускників Дніпропетровської державної медичної академії, Донецького національного медичного університету імені М. Горького, Запорізького державного медичного університету, Івано-Франківського національного медич- ного університету, Національного медичного університету імені О. О. Богомольця, Одеського національного медичного університету, суттєво не змінився середній бал у Кримському державному медичному університеті, Українській медичній стоматологічній академіі, Харківському національному медичному університеті.

Середній бал успішності випускників вищих медичних навчальних закладів IV рівня акредитації за даними практично-оріснтованого державного іспиту по Україні

\begin{tabular}{|c|c|c|c|c|c|c|}
\hline \multicolumn{2}{|c|}{ Динаміка бала успішності за 2000 та 2010 роки } & \multicolumn{2}{|c|}{ Динаміка бала успішності за 2001 та 2011} & роки \\
збільшен- \\
3000 рік
\end{tabular}

Зведені результати складання ЛІІ “Крок 2. Загальна лікарська підготовка” вітчизняними студентами, студентами-громадянами іноземних країн (англомовної та російськомовної форм навчання) впродовж 2009-2011 років наведено у таблицях 1 - 3 відповідно.

Згідно з Рішенням наради ректорів вищих медичних (фармацевтичного) навчальних закладів (наказ

MO3 України від 20.04.2010 № 08.01-47/742 “Про відкриті банки тестових завдань ліцензійних іспитів”) починаючи з 2010 р. для підготовки студентів до ЛІІ на сайті Центру тестування були розміщені банки тестових завдань ліцензійних іспитів, що привело до різкого збільшення абсолютних результатів ЛІІ. Особливо це простежується для “Крок 2. Загальна лікарська підготовка” за 2011 р. (рис. 1).

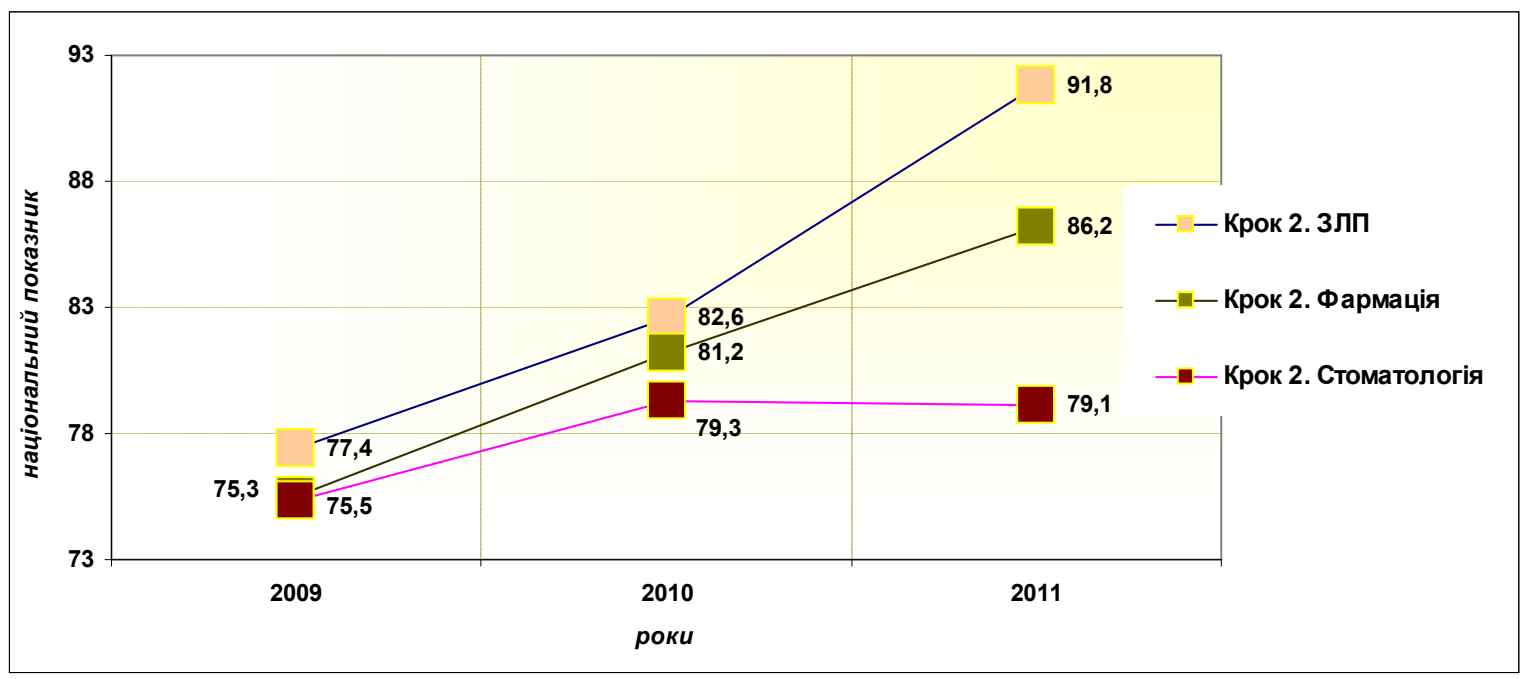

Puc. 1. Динаміка результатів складання МЛІ “Крок 2” вітчизняними студентами за 2009-2011 pp.

Зважаючи на це, ми вважаємо, що порівняння абсолютного результату іспиту є некоректним, а тому аналіз щодо підготовки студентів проведемо за показником кількості студентів, що не складають іспит.

Порівняльний аналіз результатів складання медичного ліцензійного іспиту “Крок 2. Загальна лікарська підготовка” за 2009, 2010 та 2011 роки свідчить про значне зменшення кількості студентів, що не складають іспит: у вітчизняних студентів вказаний по- казник у 2011 році порівняно 32009 роком зменшився на $0,4 \%$ для студентів бюджетної форми навчання та на 1,6 \% для студентів, що навчаються за контрактом. Привертає увагу той факт, що кількість студентів 6-го курсу, які не допущені ВН3 до державної атестації, у 2011 році порівняно з 2009 роком зменшилася майже вдвічі. Зазначене свідчить про більш якісну роботу університетів зі студентами 6-го курсу перед державною атестацією у 2011 році. 
Матеріали Всеукраїнської навчально-наукової конференції, присвяченої 55-річчю Тернопільського державного медичного університету імені І. Я. Горбачевського, “Впровадження нових технологій за кредитно-модульної системи організації навчального процесу у ВМ(Ф)НЗ ІІІ-ІV рівнів акредитаціі””

Таблиця 1. Результати складання МЛІ “Крок 2.3ЛП” вітчизняними студентами за 2009-2011 pp.

\begin{tabular}{|c|c|c|c|c|c|c|c|c|c|c|c|c|c|}
\hline \multirow[b]{2}{*}{ Рік } & \multicolumn{3}{|c|}{$\begin{array}{c}\text { ВСЬОГО } \\
\text { зареєстровано } \\
\end{array}$} & \multicolumn{5}{|c|}{$\begin{array}{l}\text { Кількість студентів, що не склали } \\
\text { іспит }\end{array}$} & \multicolumn{5}{|c|}{$\begin{array}{c}\text { Кількість студентів, що не допущені } \\
\text { ВН3 до державної атестації } \\
\end{array}$} \\
\hline & $\begin{array}{l}0 \\
0 \\
\text { Dी } \\
\text { D. }\end{array}$ & 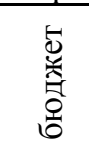 & 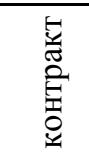 & $\begin{array}{l}0 \\
0 \\
0 \\
0 \\
0\end{array}$ & 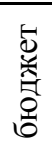 & $\partial^{\circ}$ & 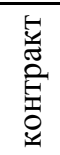 & $a^{\circ}$ & $\begin{array}{l}\stackrel{0}{0} \\
\text { D. } \\
\stackrel{0}{0}\end{array}$ & 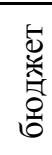 & $\partial^{\circ}$ & 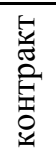 & $\partial^{0}$ \\
\hline 2009 & 5473 & 3462 & 2011 & 66 & 22 & 0,6 & 44 & 2,2 & 80 & 39 & 1,1 & 41 & 2,0 \\
\hline 2010 & 5440 & 3221 & 2219 & 84 & 30 & $\overline{0,9}$ & 54 & 2,4 & 48 & 19 & 0,6 & 29 & 1,3 \\
\hline 2011 & 4839 & 3229 & 1610 & 15 & 6 & 0,2 & 9 & 0,6 & 36 & 16 & 0,5 & 20 & 1,2 \\
\hline
\end{tabular}

Аналіз підготовки студентів-громадян іноземних країн англомовної форми навчання свідчить про збільшення кількості цих студентів, значно кращу роботу університетів 3 цим контингентом після невдалого 2010 року-останнього року за традиційною формою навчання, та суттєво кращі результати успіш- ності цих студентів у 2011 році- році першого випуску цих студентів за кредитно-модульною системою навчання.

Аналогічна тенденція спостерігається за результатами складання іспиту студентами-громадянами іноземних країн російськомовної форми навчання.

Таблиця 2. Результати складання MЛI Krok 2. Medicine студентами-громадянами іноземних країн англомовної форми навчання за 2009-2011 pp.

\begin{tabular}{|c|c|c|c|c|c|}
\hline \multirow{2}{*}{ Рік } & \multirow{2}{*}{$\begin{array}{c}\text { ВСьОГО } \\
\text { зареєстровано }\end{array}$} & \multicolumn{2}{|c|}{$\begin{array}{c}\text { Кількість студентів, що не } \\
\text { склали іспит }\end{array}$} & $\begin{array}{c}\text { Кількість студентів, що не допущені } \\
\text { ВН3 до державної атестації }\end{array}$ \\
\cline { 3 - 6 } & & всього & $\%$ & всього & $\%$ \\
\hline 2009 & 730 & 7 & 1,0 & 1 & 0,1 \\
\hline 2010 & 965 & 70 & 7,3 & 3 & 0,3 \\
\hline 2011 & 1090 & 0 & 0 & 18 & 2,7 \\
\hline
\end{tabular}

Таблиця 3. Результати складання МЛІ “Крок 2.3ЛП” студентами-громадянами іноземних країн за 2009$2011 \mathrm{pp}$.

\begin{tabular}{|c|c|c|c|c|c|}
\hline \multirow{2}{*}{ Рік } & \multirow{2}{*}{$\begin{array}{c}\text { ВСьОГО } \\
\text { зареєстровано }\end{array}$} & \multicolumn{2}{|c|}{$\begin{array}{c}\text { Кількість студентів, що не склали } \\
\text { іспит }\end{array}$} & \multicolumn{2}{|c|}{$\begin{array}{c}\text { Кількість студентів, що не } \\
\text { допущені ВН3 до державної } \\
\text { атестації }\end{array}$} \\
\cline { 3 - 6 } & & всього & $\%$ & всього & $\%$ \\
\hline 2009 & 567 & 68 & 12,0 & 5 & 0,9 \\
\hline 2010 & 666 & 66 & 9,9 & 3 & 0,5 \\
\hline 2011 & 747 & 11 & 1,5 & 10 & 1,3 \\
\hline
\end{tabular}

Отже, попередні результати державної атестації випускників вищих медичних навчальних закладів IV рівня акредитаиії МОЗ України у 2011 роиі у порівнянні з роками до впровадження кредитно-модульної системи організації навчального прочесу свідчать про деякі позитивні зміни показників успішності студентів після впровадження кредитно-модульної системи організаціі навчального процесу.

У зв'язку з цим наводимо пропозиції щодо подальших шляхів поліпшення підготовки лікарів:

1. Затвердження Міністерством освіти і науки, молоді та спорту України пакета нормативних документів, які регламентують навчання студентів за кредитно-модульною системою організації навчаль- ного процесу, забезпечення мобільності студентів, механізми реалізації програм міжуніверситетської співпраці.

2. Удосконалення МОЗ України галузевих стандартів вищої медичної та фармацевтичної освіти 3 метою приведення їх у відповідність до сучасних вимог з урахуванням євроінтеграційного вектора вищої освіти та реформування сфери охорони здоров'я.

3. Затвердження Кабінетом Міністрів України Державної програми розвитку галузевої освіти з метою цільового фінансування вищих навчальних закладів, як центрів реформування, на конкретний результат.

4. Розробка Міністерством освіти і науки, молоді та спорту України механізму фінансування (еконо- 
мічної підтримки) органів студентського самоврядування та розвитку інфраструктури вищих навчальних закладів.

5. Удосконалення МО3 України порядку визначення та розміщення обсягів державного замовлення на підготовку фахівців серед вищих навчальних закладів.

6. Дотримання вищими навчальними закладами нормативів чисельності студентів (курсантів), аспірантів (ад’юнктів), докторантів, здобувачів наукового ступеня кандидата наук, слухачів, інтернів, клінічних ординаторів на одну штатну посаду науково-педагогічного працівника у вищих навчальних закладах III i IV рівня акредитації та вищих навчальних закладах післядипломної освіти державної форми власності, визначених постановою Кабінету Міністрів України від 17.08.2002 № 1134.

7. Приведення обсягів фінансування вищих навчальних закладів МО3 України та розміщення державного замовлення на підготовку фахівців відповідно до вимог наказу МОЗ України від 23.11.2005 № 632 "Про затвердження Примірних нормативів матеріально-технічного забезпечення кафедр вищих медичних (фармацевтичного) навчальних закладів та закладів післядипломної освіти III-IV рівнів акредитації, підпорядкованих МОЗ України”.

8. Внесення змін до статті 85 Бюджетного кодексу України в частині заборони здійснення видатків на функціонування бюджетних установ одночасно 3 двох бюджетів, встановивши виняток для вищих медичних навчальних закладів та закладів післядипломної освіти, що пов'язано з необхідністю поліпшення практичної підготовки лікарів на клінічних кафедрах, розташованих на базі закладів охорони здоров' я комунальної форми власності.

9. Завершення роботи по створенню єдиних національних підручників та поліпшення забезпечення студентів сучасними підручниками і посібниками з усіх дисциплін.

\section{Література}

1. Льовенське комюніке Болонського процесу - український переклад від Свропейського освітнього порталу (05.05.2009).

2. Про затвердження та введення нового навчального плану підготовки фахівців освітньо-кваліфікаційного рівня “спеціаліст” кваліфікації “лікар” у вищих медичних навчальних закладах України III-IV рівнів акредитації України за спеціальностями “Лікувальна справа”, “Педіатрія”, “Медико-профілактична справа” : наказ МОЗ України від
10. Створення та використання в навчальному процесі міжкафедральних навчально-тренінгових центрів практичної підготовки.

11. Впровадження в навчальних процес дистанційних інтернет-технологій навчання.

12. Поліпшення виховної роботи з метою формування у студентів як професійних, так і соціальних компетенцій, необхідних у діяльності лікаря.

13. Поліпшення організації навчання та якості підготовки іноземних студентів.

3 метою забезпечення координації роботи вищих медичних (фармацевтичного) навчальних закладів, спрямованої на реалізацію державної політики у галузі медичної освіти, зокрема з удосконалення змісту навчання, покращання якості медичної та фармацевтичної освіти та іiі інтеграції в європейське і світове співтовариство наказом МОЗ України від 27.04.2011 № 238 створено Координаційну науково-методичну раду з вищої медичної освіти, до складу якої увійшли представники усіх вищих медичних (фармацевтичного) навчальних закладів України III-IV рівнів акредитації [3].

Необхідно підкреслити, що у п. 9 БудапештськоВіденської декларації про створення Свропейського простору вищої освіти наголошено: "Ми визнаємо ключову роль академічної спільноти - керівників закладів, викладачів, дослідників, адміністративного персоналу та студентів-у втіленні Свропейського простору вищої освіти, забезпечуючи тих, хто навчається, можливостями для отримання знань, умінь і компетенцій для побудови їхньої кар'єри та життя як громадян демократичних країн, а також їх особистісного розвитку. Ми усвідомлюємо потребу в сприятливіших умовах для виконання своїх завдань працівниками вищих навчальних закладів. Ми зобов'язуємося працювати над більшим залученням працівників вищої освіти та студентів до запровадження і подальшого розвитку Свропейського простору вищої освіти..."

\subsubsection{5 №52.}

3. Про створення Координаційної науково-методичної ради з питань медичної освіти : наказ МО3 України від 27.04.2011 № 238 .

4. Підаєв А. В. Болонський процес в Свропі. Що таке і чи потрібний він Україні? Чи можлива інтеграція медичної освіти України в Європейський освітній простір? / А. В. Підаєв, В. Г. Передерій. - Одеса : Одес. держ. мед. ун-т, 2004. -190 с. 